\title{
Effect of Teacher Readiness on the Implementation of Competency Based Curriculum in Public Primary Schools in Awendo Sub County, Migori County, Kenya
}

\author{
Oguta, $\mathrm{J}^{1 *}$, Osoro, E. $\mathrm{N}^{2}$. \\ Africa Nazarene University \\ Email: joseph.oguta@yahoo.com
}

\begin{abstract}
The purpose of this research was to evaluate the effect of teacher readiness on the implementation of Competency Based Curriculum (CBC) in public primary schools in Awendo Sub County, Migori County, Kenya. The objective of this study was to examine the effect of teachers' motivation, in public primary schools in Awendo Sub - County. The research applied the Pedagogical Content Knowledge Theory. The study used a descriptive survey research design. The target population was 1741 respondents comprising 1666 grade one to four teachers and 75 head teachers. The researcher used simple random sampling in selecting the sample size for both grade one to four teachers and head teachers. Thirty percent of 1666 grade one to four teachers and 75 head teachers were selected to constitute a sample size of 500 CBC teachers and 23 head teachers. Data was collected through Teachers' questionnaire and HT's interview schedule. Reliability and validity were approximated through research instruments. Pilot testing was conducted in the neighboring Rongo Sub - County. Reliability of the research instruments were calculated using split half method obtaining a coefficient of 0.8 . Content and construct validity were ascertained through the University supervisors' scrutiny and pilot testing. Both descriptive and inferential statistics were used to analyze the data. The study findings revealed that motivation of teachers had statistically significant effect while teacher in- service was moderate. The study's other independent variables contributed $63.7 \%$ of variables in the level $\mathrm{CBC}$ implementation in teaching and learning $\left(\mathrm{R}^{2}=0.637\right)$. Teacher motivation was the most potent predictor of CBC implementation. $\beta=0.960, \mathrm{t}(18)=3.169, \rho<0.05)$. The study therefore, recommends that material rewards should be given to teachers for them to do better in all areas in the school and for encouragement. The school management should also ensure that school environment is conducive for teachers by offering accommodation and food to ensure their motivation and satisfaction with their jobs.
\end{abstract}

Keywords: Competency based curriculum, Resources, competencies, Readiness

DOI: $10.7176 / \mathrm{JEP} / 13-5-04$

Publication date: February $28^{\text {th }} 2022$

\subsection{Background of the Study}

Competency Based Curriculum (CBC) was introduced by the Kenyan government after a summative evaluation of 8-4-4 system of education in 2009. The Kenya Institute of Curriculum Development (KICD), 2017) established that the major objectives of 8-4-4 curriculum were not being achieved. The system was more theoretical; exam oriented and did not consider psychomotor and affective skills. Teaching learning materials were of low quality and therefore, did not meet the demand of a knowledge-based economy.

These gaps informed the decision to change from 8-4-4 system to Competency Based Curriculum (International Bureau of Education (IBE, 2017). This new system was expected to produce individuals who are creative, critical thinkers, innovative and can compete effectively in the job market globally. However, several stakeholders have raised concern over teacher readiness to implement the new curriculum (Mulenga \& Kabombwe, 2015).

Competency Based Curriculum has been appreciated around the world as a means through which a country empowers its citizens with essential values, knowledge, attitudes, and skills for individual and national development (United Nations Educational, Scientific and Cultural Organization (UNESCO, 2014).The new curriculum promotes learners acquisition of $21^{\text {st }}$ century skills of application of knowledge and creativity. It is learner centered and teachers become facilitators of learning rather than center of information. The center of interest is on learners' acquisition of skills, values and knowledge and the application of the competencies to real life situations (Kihumba \& Kennedy, 2019). Most competencies targeted by CBC include; communication and collaboration, critical thinking and problem solving, creativity and imagination, learning to learn, digital literacy and self-efficacy (KICD, 2019).

The Competency Based Curriculum programs are flexible and accommodative. The focus is on formative assessment which is continuously carried out during the learning process. Various approaches used in CBC include; active learning, field trips, role-play, debates, demonstration, question and answer methods, and teacher exposition. This new system of education produces learners that are all holistic, cooperative and analytical in the society (West \& West, 2016). 
Competency Based Curriculum promotes skills-based learning. All engagements with the learners are geared towards the application of competencies rather than rote learning of the content. The result is that the students become confident and experts in their own chosen careers. It also identifies learners' strengths, weaknesses, interests, abilities, motivations and their understanding of how these factors relate to other contexts of their lives and the ideas about how they will view themselves in the future (Martine, 2014).

United States of America, Singapore, New Zealand, Malaysia, South Korea and Australia are among countries with top notch education system in the world. In New Zealand Competency Based Curriculum was introduced to ensure that all learners' future participation in both community and economy is embraced. Key competencies like thinking, use of language symbols and texts, managing self-relation to others, participation and contribution were to be applied as an essential role in achieving the goals of Competency Based Curriculum (Bolstand, 2012). The Australian Curriculum Assessment and Reporting Authority (ACARA) developed a curriculum that provided teachers, parents, learners and all education stakeholders with clear and simple understanding of what was to be learnt and how it was to be learnt regardless of where they lived or which school they attended in Australia (ACARA, 2016).

The implementation of this new system in Kenya has met several challenges from stakeholders who are not satisfied with the level of teacher readiness. The teachers through their union said that they were not ready to take learners through $\mathrm{CBC}$ because the due process was compromised (Kenya National Union of Teachers [KNUT], 2019). According to Ondimu (2018), no meaningful teaching and learning takes place without adequate teaching learning resources, teacher motivation, teacher retooling and effective atmosphere. This study concentrated on examining how teachers' motivations affect the implementation of Competency Based Curriculum in public primary schools in Awendo Sub County, Migori County, Kenya.

\subsection{Literature Review}

Motivation in teaching profession plays a very important role; it can either be intrinsic or extrinsic. In this study, extrinsic motivation of teachers included administered rewards like free accommodation, free food and drinks, extra lessons allowances and medical allowances among others. For the sake of this research, intrinsic motivations included; happiness in teaching, recognition and teaching as ones career choice. According to Wadesango (2012), motivation is a way of empowering teachers in the profession. This involves shaping their attitudes and perceptions by school management for the purpose of improving favorable working environment for the teachers to perform their tasks.

The quality of education might be negatively affected if the schools do not support and encourage teachers for their individual and professional development. Such supports like accommodation, provision of water and food will show the teachers that their efforts are being appreciated. This will in turn push the teachers to put more efforts for the benefit of the learners and school as a whole. Teachers need encouragements, appreciation, rewards and general good working atmosphere which motivate them to teach effectively

Many studies have been conducted in developed countries like USA, UK, and China among others on the effect of enhancing workers performance, the result shows no difference. In China, a study conducted by Fauziah, Tan and Mohammed (2013) established that extrinsic factors motivated young generation workers while intrinsic motivators demotivated them. On the contrary, the study revealed that intrinsic factors were found to motivate the older generation workers, while the extrinsic factors demotivated them.

Tehseen and Hadi (2015) cited in their study that teachers' satisfaction and motivation is influenced by teacher characteristics, wages, school practices, governance and working conditions. Out of 288 respondents, 63 percent confirmed that good working condition had the highest effect on teachers' retention and performance. The report further established that talented teachers were to be maintained and motivated for the achievement of school goals and maintenance of good performance.

In Ghana, a research conducted by Agebure (2013) established that the basic principle of motivation was based on individuals' efforts. The study found out that teacher's appreciation through rewards and incentives for good performance enhanced work commitment, increased engagement with the learners and this led to improved academic performance. The study focused on several motivational practices in schools as a variable of effect of teacher readiness on $\mathrm{CBC}$ implementation.

Kitila (2012) conducted a study in Tanzania on teachers commitment in teaching profession established that loyalty of teachers on the teaching profession was very low. Majority of teachers confirmed that they were forced into teaching profession because it was the easiest way of employment since they did not meet the basic requirements of other professions. This study was carried out to find out if motivation had an effect on teacher readiness. Ireri (2015) in a study on motivation of employee's performance in non-governmental institutions in Kenya revealed that there were significant relationship between motivation and performance. The study was based on compensation, promotion and supervision of employee's performance.

A study by Kingi (2018) on academic self-concert, motivation and resilience among secondary school students in Nairobi County revealed that teacher's level of participation in curriculum management had significant 
effect on their motivation. The study used correlation design and was anchored on change management model of Hertzberg motivation theory. The current study employed descriptive survey design based on Pedagogical Content Knowledge theory to find out the effect of teacher readiness on the implementation of competency based curriculum.

Kariuki and Mbugua (2018) conducted a study on the influence of teacher's motivation on Academic performance in Public Secondary Schools in Nyeri and Kirinyaga County. The research realized that there was need to focus on teachers' motivation given their responsibilities to impart knowledge, skills, and attitudes to the learners. They also found out that satisfied teachers were very productive and had effect on learner's academic achievement.

\subsection{Research Design and Methodology}

A descriptive cross sectional survey research design was adopted with both qualitative and quantitative approaches. According to Picho (2014), in a cross sectional survey design, does not require a follow up activity on the respondents.

\subsection{Target Population and Sample size}

The target population of this study was; all Primary School head teachers and teachers currently handling grade one to four Competency Based Curriculum in Awendo Sub County thus, the total target population targeted was 1,741 respondents as shown on Table 3.1. The accessible population of this study was; all Head teachers and grade one to four Teachers in 75 Public Primary Schools in Awendo Sub County, Migori County, Kenya.

The researcher used simple random sampling to select the sample size from the target population of 75 head teachers and 1,666 teachers handling grade one to four in public primary schools in Awendo Sub County. Mugenda and Mugenda, (2003) assert that sample size of ten to thirty percent of the target population is sufficient for generalization. The researcher, therefore, used $30 \%$ of the target population constituting a sample size of 500 grade one to four teachers and 23 head teachers. The study involved the use of questionnaires and interview schedules as tools for data collection. These tools were appropriate for this study because according to Kathuri and Pals (1993), most techniques for measuring social and psychological aspects of environment rely on questionnaires and interviews.

The research instrument was discussed with supervisors and colleagues within the department to improve on its content validity. Content validity was used to test the validity of the instruments and it was achieved by ensuring that test items covered all variables and objectives of the study. Whereas instrument reliability was estimated using split-half technique. A coefficient of 0.8 in grade one to four teachers' questionnaires and head teacher's interview was obtained. This was considered appropriate for the study because Pina (2014) recommends a reliability of 0.7 and above as a strong reliability.

\subsection{Data Analysis}

Qualitative data from the interview schedule and questionnaires were analyzed through thematic content analysis. From the questionnaires, both descriptive and inferential statistics were computed after sorting, scoring, coding and analyzing the data collected. Descriptive statistics in the form of frequencies and percentages were computed so as to determine the questionnaire response rate and the rate at which $\mathrm{CBC}$ was implemented in primary schools. This helped in generating reports for further statistical analysis. Regression analysis was applied to determine the predictive capacity of each of the teacher readiness practices on the implementation of the Competency Based Curriculum. From the regression analysis, a coefficient of determination was calculated to determine the proportion of variations in Competency Based Curriculum implementation that were explained by variations in teacher readiness practices

\subsection{Teacher Motivation and CBC Implementation}

The study examined how teachers' motivation affected the implementation of Competency Based Curriculum in public primary schools. A total of 463 grade one to four teachers were given some statements where they were required to indicate their agreement and disagreement levels with each statement. The statements were categorized into intrinsic motivation and extrinsic motivation. A 5 point Likert scale was used. Whereby; 5-Strongly agree; 4Agree; 3-Neutral; 2-Disagree; 1-Strongly Disagree. The responses obtained have been indicated on Table 1. 
Table 1: Responses on Teacher Motivation and CBC Implementation

\begin{tabular}{|c|c|c|c|c|c|c|c|c|c|c|c|c|}
\hline \multirow{2}{*}{$\begin{array}{c}\text { Statements } \\
\text { Intrinsic motivation }\end{array}$} & \multicolumn{2}{|c|}{1} & \multicolumn{2}{|c|}{2} & \multicolumn{2}{|c|}{3} & \multicolumn{2}{|c|}{$T$} & \multicolumn{2}{|c|}{5} & \multirow[t]{2}{*}{$\mathbf{M}$} & \multirow[t]{2}{*}{ SD } \\
\hline & $(f)$ & $(\%)$ & (f) & $(\%)$ & (f) & $(\%)$ & (f) & $(\%)$ & $(f)$ & $(\%)$ & & \\
\hline $\begin{array}{l}\text { Teaching profession was } \\
\text { my priority }\end{array}$ & 5 & 1.07 & 17 & 3.67 & 9 & 1.94 & 248 & 53.56 & 184 & 39.74 & 3.28 & 0.72 \\
\hline $\begin{array}{l}\text { Teaching is a noble } \\
\text { profession }\end{array}$ & 12 & 2.53 & 23 & 4.97 & 5 & 1.08 & 203 & 43.84 & 220 & 47.52 & 3.27 & 0.73 \\
\hline $\begin{array}{l}\text { Teaching CBC gives me } \\
\text { satisfaction }\end{array}$ & 43 & 9.29 & 235 & 50.76 & 17 & 3.67 & 121 & 26.13 & 47 & 10.15 & 3.27 & 0.73 \\
\hline $\begin{array}{l}\text { Teaching was my dream } \\
\text { career }\end{array}$ & 8 & 1.73 & 87 & 18.79 & 4 & 0.86 & 211 & 45.57 & 153 & 33.05 & 3.20 & 0.80 \\
\hline $\begin{array}{l}\text { Teaching CBC makes } \\
\text { me earn recognition } \\
\text { from learners and } \\
\text { community }\end{array}$ & 283 & 61.12 & 102 & 22.03 & 2 & 0.43 & 49 & 10.58 & 27 & 5.83 & 3.23 & 0.77 \\
\hline Extrinsic motivation & & & & & & & & & & & & \\
\hline $\begin{array}{l}\text { My monthly pay meets } \\
\text { my basic needs }\end{array}$ & 19 & 4.10 & 54 & 11.66 & 7 & 1.51 & 302 & 65.23 & 81 & 17.50 & 3.41 & 0.59 \\
\hline $\begin{array}{l}\text { There are enough CBC } \\
\text { teaching learning } \\
\text { materials }\end{array}$ & 69 & 14.90 & 201 & 43.41 & 21 & 4.54 & 92 & 19.87 & 80 & 17.28 & 3.31 & 0.70 \\
\hline $\begin{array}{l}\text { My school provides } \\
\text { conducive environment } \\
\text { for CBC learning }\end{array}$ & 56 & 12.10 & 292 & 63.07 & 15 & 3.24 & 63 & 13.61 & 37 & 7.99 & 3.05 & 0.95 \\
\hline $\begin{array}{l}\text { My school encourages } \\
\text { hardworking grade one } \\
\text { to four teachers by } \\
\text { giving them rewards }\end{array}$ & 43 & 9.29 & 251 & 54.21 & 3 & 0.65 & 101 & 21.81 & 65 & 14.04 & 3.27 & 0.73 \\
\hline $\begin{array}{l}\text { My school pays for } \\
\text { every extra CBC } \\
\text { lessons covered }\end{array}$ & 109 & 23.54 & 280 & 60.48 & 0 & 0 & 53 & 11.45 & 21 & 4.54 & 3.20 & 0.80 \\
\hline $\begin{array}{l}\text { My school } \\
\text { accommodates CBC } \\
\text { teachers }\end{array}$ & 77 & 16.63 & 317 & 68.47 & 3 & 0.65 & 57 & 12.31 & 9 & 1.94 & 3.10 & 0.73 \\
\hline $\begin{array}{l}\text { My school provides } \\
\text { water and food for CBC } \\
\text { teachers }\end{array}$ & 85 & 18.36 & 324 & 69.98 & 14 & 3.02 & 31 & 6.70 & 9 & 1.94 & 3.37 & 0.63 \\
\hline
\end{tabular}

\section{$\mathrm{n}=463$.}

SD: Standard Deviation, M: Mean

The results on Table 1 shows that more than three quarters of the grade one to four $53.6 \%$ agreed that teaching profession was their priority. Those who strongly agreed and were neutral were $39.74 \%$ and $1.94 \%$ respectively. However, $3.67 \%$ disagreed and $1.07 \%$ strongly disagreed. This notwithstanding, the teaching profession as their priority had the Mean of 3.28 with a corresponding Standard Deviation of 0.72. When asked whether teaching was their noble profession, combined percentage of $91.36 \%$ who were the majority agreed (Mean=3.27, $\mathrm{SD}=0.73$ ), $1.08 \%$ were neutral while $4.97 \%$ and $2.53 \%$ disagreed and strongly disagreed respectively. Whether teaching CBC gave them satisfaction, majority $\{235$ (50.76\%), Mean $=3.27, \mathrm{SD}=0.73\}$ disagreed, $26.13 \%$ agreed and $3.67 \%$ were neutral. Those who strongly agreed and strongly disagreed were $10.15 \%$ and $439.29 \%$ respectively. One of the teachers from school B commented:

Teaching profession doesn't pay well; I wanted to pursue other careers but ended up in teaching (T297).

Majority of the grade 1 to 4 teachers $\{211(45.57 \%)$, Mean $=3.20, \mathrm{SD}=0.80\}$ agreed that teaching was a dream career, $33.05 \%$ strongly agreed and those who were neutral were $0.86 \%$. Those who disagreed and strongly disagreed were $18.79 \%$ and $1.73 \%$ respectively. The researcher also established whether teaching CBC makes them earn recognition from learners and community, majority of them $61.12 \%$ strongly disagreed, $22.03 \%$ disagreed while only $0.43 \%$ were neutral. One of the experienced teachers commented that:

In our school, teachers' opinions and decisions are disregarded. The school is not convenient in terms of accessibility and the teachers are not respected by the community (T46).

The implication was that there was an absence of a suitable scheme of payment to guarantee commitment to job performance in most public secondary schools in Awendo Sub County, as most grade 1 to 4 teachers were running battles with employer over implementation of such, hence are a generally demoralized lot leading to 
ineffective job performance therefore affecting the effective implementation of $\mathrm{CBC}$. On adequacy of $\mathrm{CBC}$ teaching and learning materials, $17.28 \%$ strongly agreed that they were adequate, $19.87 \%$ agreed, $4.54 \%$ were neutral. Contrary, $14.90 \%$ strongly disagreed while the majority $\{201(43.41 \%)$, Mean=3.31, $\mathrm{SD}=0.70\}$ disagreed on adequacy of $\mathrm{CBC}$ teaching learning materials.

The findings revealed that most teachers are demoralized. While responding on motivation, a teacher with 15 years' experience from one of the sampled schools gave the following comment:

We grade one to four teachers need to be motivated through allowances for extra Competency Based Curriculum lessons covered, given accommodation in school or by provision of food and clean water in schools. For instance, our school provides monetary awards for teachers who demonstrate high performance for every ' $\mathrm{A}$ ' scored in their teaching subjects. $\mathrm{CBC}$ is different and has no grading system; we are normally seen as not working very hard in our teaching grades (T 47).

Only $6.70 \%$ and $1.94 \%$ of the grade 1 to 4 teachers agreed and strongly agreed respectively that school provides water and food for $\mathrm{CBC}$ teachers $18.36 \%$ strongly disagreed, $3.02 \%$ were neutral while the majority $\{324$ (69.98\%), Mean=3.37, $\mathrm{SD}=0.63\}$ disagreed.

Researcher went further to examine the effect of teacher motivation and the implementation of the Competency Based Curriculum. Pearson's Correlation Coefficient was computed to show the kind of relationship that existed between the two variables. The summary of the findings are shown on Table 2 .

Table 2: Correlation between Teacher Motivation and Implementation of CBC

\begin{tabular}{llc}
\hline Pearson Correlation $(\mathrm{r})$ & Teachers' Motivation & Implementation of CBC \\
\hline Pearson correlation & $.844^{* *}$ & 1 \\
Sig. (2-tailed & .0001 & \\
$\mathrm{~N}$ & 463 & \\
\hline$* *$ Correlation is significant at the 0.05 level (2-tailed)
\end{tabular}

** Correlation is significant at the 0.05 level (2-tailed)

The analysis of Pearson Correlation Coefficient on Table 2 indicated that there was a strong and positive correlation $(r=.844, p$-value $<0.05)$ between implementation of Competency Based Curriculum (dependent variable) and teachers' motivation in public primary schools in Awendo Sub County in Migori County, Kenya. The correlation was tested for statistical significance and the results obtained showed that the correlation coefficient was statistically significant since the $\mathrm{p}$-value was less than the significance level $(p$-value $<0.05)$.

\subsection{Discussions}

The research revealed that more than half of the schools had no proper motivational policies. The study indicated that there was a strong and positive correlation $(r=.844, p$-value $<0.05)$ between teachers' motivation and the implementation of Competency Based Curriculum. The null hypothesis that there was no statistically significant effect of teacher motivation on the implementation of $\mathrm{CBC}$ was rejected. From the findings of the study, it can be said that the absence of institutional motivation policies affects grade one to four teacher motivation in public primary schools in Awendo Sub County.

Nyakongo (2015) advocates that there should be an effective reward system to retain the high performers in the organization and reward should be related to their productivity. In order to maximize the performance of the employees in an organization, one must make such policies which increase employee satisfaction and motivation. The study realized that majority of the teachers, $58.10 \%$ enjoyed teaching CBC in public primary schools in Awendo Sub County. This implied that over time they had learnt to enjoy teaching the CBC and had gained the confidence to do so. This is in agreement with Andiema (2015) who asserts that all factors being constant, it is agreed that a teacher gains skills through experience and the more the experience a teacher has, the more successful the work becomes.

Those who never enjoyed teaching $\mathrm{CBC}$ indicated that inadequacy of teaching and learning materials was the main challenge they faced when teaching the $\mathrm{CBC}$ that made them to be reluctant and never enjoyed teaching CBC. This slowed down the implementation process of $\mathrm{CBC}$, thus impacting on it negatively. This finding corroborates with the findings by Akungu (2014) who asserted that teaching and learning cannot be effective without adequate and relevant use of instructional materials. According to Muthima (2015) instructional resources in teaching and learning make students to learn better and retain much of what they have been taught and that it also promotes and sustains students' interest. It also allows the learners to discover themselves and their abilities and consequently provides them with an opportunity to realize their full potential.

In support of these findings, Erkaya (2012) established that workers' motivation affects production; poorly motivated staff was noted as costly to the institutions in terms of lower productivity and performance, chronic absenteeism and low teachers' morale. The study acknowledged that teachers performed best when they expected to receive allowances like leave and rent that were paid regularly. The payment motivated educators to achieve greater employee commitment and devotion to work. As Wadesango (2012) asserts, motivation is a way of empowering teachers in the profession. This involves shaping their attitudes and perceptions by school management for the purpose of improving favorable working environment for the teachers to perform their tasks. 
The quality of education might be negatively affected if the schools do not support and encourage teachers for their individual and professional development.

\subsection{Recommendation}

Thus, in terms of practice the study recommends that material rewards should be given to teachers for them to do better in all areas in the school and for encouragement. This is due to the fact that material rewards play a crucial role in encouraging and motivating teachers. Moreover, the school management should ensure that school environment is conducive for teachers by offering accommodation and food to ensure their motivation and satisfaction with their jobs.In terms of policy, the government through Teacher's Service Commission should enact policies driven to promote teachers on the merit of paying them well, increase teachers' remuneration, review teachers' pay in relation to the teachers work and standards of living and to employ more teachers to release their workload as a motivational strategy for them to ensure quality Competency Based Curriculum delivery.

\section{References}

Agebure, A. (2013). The state of teachers' participation in decision making in public senior secondary school in the Bolgatanga Municipality in Ghana. Journal of Education and Practices, 4 (22), 25-38.

Australian Curriculum and Reporting Authority. (2016). Collaboration Problem-Solving Online Assessment and Australian Curriculum (Melbourne Declaration on Educational Goals for Young Australians). Australia.

Bolstand, R. (2012). Principles for the future-oriented education system. New Zealand annual review of education.Hachette New Zealand Publishers.

Erkaya .O. R. (2012).Factors that motivate Turkish EFL teachers. International Journal of Research Studies in Language Learning. 2 (2), 49-61.

Fauzia, W., Tan, S,.K., \& Mohammad, T.M. (2013). Herzberg's two factor theory on work motivation: Does it work in today's environment? Global Journal of Commerce and Management Perspective GJCMP 2 (5), $18-22$.

International Bureau of Education. (2017). The competency based curriculum reforms; The Kenyan experience. The Journal on current and Critical Issues in Curriculum, Learning, and Assessment in Progress Reflection, 3 (2), 53-62.

Ireri, C. M. (2015).Influence of motivation on employee performance in non-governmental institutions. A Case of Kenya Tenri society in Embu County. (Unpublished research project) University of Nairobi.

Kariuki, M., G., \& Mbugua, Z. (2018). Influence of Student Motivation by Teachers on Academic Performance in Public Secondary Schools in Nyeri and Kirinyaga Sub-Counties, Kenya. (MED) Nairobi University

Kenya Institute of Curriculum Development (2016). Report needs assessment for primary level school's curriculum in Kenya. Nairobi Kenya.

Kenya National Union of Teachers (2019). Teachers' preparedness on Implementation of Competency Based Curriculum in Pre - Primary and Lower Primary Grades: Nairobi: Kenya National Union of Teachers.

Kenya Institute of Curriculum Development (2019).Reports on needs assessment for primary level school curriculum in Kenya. Nairobi Kenya.

Kihumba, K., \& Kennedy, B. (2019). Learner-centered system emphasizing application of knowledge and skills. Journal of Teachers Image, 6 (1), 8-9.

Kitila, A. (2012). Teachers 'commitment and Experience in teaching profession in Tanzania: Findings of focus Group research department of educational psychology and curriculum studies. International Education Studies, 5 (3), 222-229.

Kingi, P. M (2018). Academic self-concert, motivation and resilience as predictors of Mathematics achievement among secondary school students in Nairobi County, Kenya. (Unpublished M. Ed thesis).Nairobi University.

Martine, P. (2014). Factors influencing implementation of curriculum in public primary schools in Ukwala Division of Siaya County, Kenya. (M.ed) Nairobi University.

Mulenga, I.M., \& Kabombwe, Y. (2015). Competency based curricular for Zambian primary and secondary schools: Learning from theory and other counties in the world. International Journal of Education and Research, 7 (2), $117-130$.

Mugenda, M. O., \& Mugenda, A. G. (2003). Research Methods; Quantitative And Qualitative Approaches. Nairobi: ACTS Press.

Muthima, N. W. (2015). Adequacy and quality of teaching and learning resources in public primary schools in Ndaragwa Division, Nyandarua County, Kenya (Doctoral dissertation, Egerton University).

Nyakongo, O. H. (2015). Influence of motivation on teachers' job performance in public secondary schools in Rachuonyo South Sub-County, Homa-Bay County: Kenya.(Unpublished Master Degree Project, Kenyatta University).

Ondimu, S. (2018). Teachers preparedness on implementation of competency based curriculum in private pre- 
schools in Dagoretti North Sub County, Nairobi County, Kenya. (M.Ed thesis). Nairobi University.

Picho, E. O. (2014).The Relationship Between Employee Training And Development And Job Satisfaction In Uganda Management Institute: An Empirical Study. Global Journal of Commerce And Management, 3 (4), $182-188$.

Tehseen, S., \& Hadi, N.(2015).Factors influencing teachers' performance and retention. Mediterenial Journal of Social Science, 1 (6), 56-74.

United Nations Educational, Scientific and Cultural Organization. (2014), Education for all global monitoring report 2013/2014; teaching and learning: Achieving quality for all. Paris: UNESCO Publishing.

Wadesango, N. (2012. The influence of teacher participation in Decision making in their occupational morale. Journal of Social Science, 3 (8), 361-369.

West, J., \& West, C., K. (2016). Integrating differentiation in English education methods courses: Learning from the perceptions and experiences of teacher candidates: The Teacher Educator, 3 (7), 115 - 135. 